\title{
ELECTRONIC STRUCTURE AND MAGNETIC PROPERTIES OF INTERMETALLIC ALLOYS
}

\author{
A. Jezierski, M. Pugacheva, J.A. Morkowski and A. Szajek \\ Institute of Molecular Physics, Polish Academy of Sciences \\ Smoluchowskiego 17, 60-179 Poznań, Poland
}

\begin{abstract}
We present the influence of local ordering on the electronic and magnetic properties of Heusler-type alloys. The band structure and magnetic moments are calculated by $a b$ initio spin-polarized tight binding linear muffin-tin orbital method. The calculated electronic density of states for $\mathrm{Pd}_{2} \mathrm{TiAl}$ alloy is similar to ultraviolet photoelectron spectroscopy measurements. The self-consistent band calculations showed that the density of states at the Fermi level in $\mathrm{Ni}_{2}\left(\mathrm{Nb}_{(1-x)} \mathrm{Ti}_{x}\right) \mathrm{Sn}$ and $\mathrm{Ni}_{2}\left(\mathrm{Nb}_{(1-x)} \mathrm{Ta}_{x}\right) \mathrm{Sn}$ alloys decreased with the increase in $\mathrm{Ti}$ or $\mathrm{Ta}$ concentration. The total and local magnetic moments in ordered $\mathrm{Rh}_{2} \mathrm{TMSn}(\mathrm{TM}=\mathrm{Mn}, \mathrm{Fe}, \mathrm{Co}, \mathrm{Ni}, \mathrm{Cu})$ and $\mathrm{Rh}_{2} \mathrm{MnX}$ $(\mathrm{X}=\mathrm{Al}, \mathrm{Ga}, \mathrm{In}, \mathrm{Ge}, \mathrm{Sb}, \mathrm{Pb}$ ) Heusler-type alloys are calculated. The difference between theoretical and experimental results can be connected to the partial disorder in the samples.
\end{abstract}

PACS numbers: 71.20.-b, 75.10.Lp

\section{Introduction}

In the last years the problem of magnetism in new Heusler-type alloys was studied experimentally and theoretically [1-37]. Two physical problems in the systems which crystallize in $L 2_{1}$-type structure are particularly interesting. The first problem is connected to the influence of local environment on the magnetic properties (e.g. $\mathrm{Co}_{2-x} \mathrm{Ni}_{x} \mathrm{TiSn}, \mathrm{CoTi}_{1-x} \mathrm{Al}_{x}$ or $\mathrm{Ni}_{2}\left(\mathrm{Nb}_{(1-x)} \mathrm{T}_{x}\right) \mathrm{Sn}$ for $\mathrm{T}=\mathrm{Ti}$ and $\mathrm{Ta}$ ) and the second one is the magnetism in the systems whose elements are non-magnetic $\left(\mathrm{Pd}_{2} \mathrm{TiX}\right.$ for $\mathrm{X}=\mathrm{Al}, \mathrm{Sn}$ and $\left.\mathrm{In}\right)$. In this paper we present the results of $a b$ initio self-consistent tight binding linear muffin-tin orbital (TB-LMTO) calculations of the electronic structures and magnetic moments in the Heusler-type systems and compare them with the available experimental data. In the $\mathrm{TM}_{2}$ TiSn alloys (TM $=\mathrm{V}, \mathrm{Cr}, \mathrm{Mn}, \mathrm{Fe}, \mathrm{Co}, \mathrm{Ni}, \mathrm{Cu}$ and $\mathrm{Pd}$ ) the magnetism is due to TM atom. The values of the magnetic moments depend on the position of transition metals in $L 2_{1}$ cell. Recently, Pierre et al. [13, 14] studied the electronic and magnetic properties of $\mathrm{Co}_{2-x} \mathrm{Ni}_{x}$ TiSn and $\mathrm{Co}_{1-x} \mathrm{Ni}_{x}$ aTiSn Heusler-type alloys. They observed that the magnetic moment decreased during the substitution of Co by $\mathrm{Ni}$ atoms and in the $\mathrm{Ni}_{2} \mathrm{TiSn}$ alloy the total magnetic moment went to zero. In the $\mathrm{Co}_{1-x} \mathrm{Ni}_{x}$ aTiSn 
systems Pierre et al. $[13,14]$ observed the transition from ferromagnetic metallic

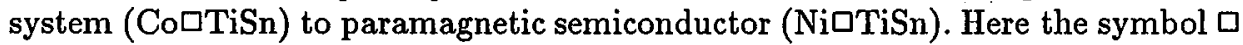
denotes the vacancies. The interesting experimental results for $\mathrm{Co}_{2-x} \mathrm{Ni}_{x}$ TiSn and $\mathrm{Co}_{1-x} \mathrm{Ni}_{x}$ पTiSn alloys have been confirmed by ab initio calculations of Tobola et al. [37] (KKR and KKR-CPA methods) and Jezierski [36] (LMTO method). The effect of local environment in $\mathrm{CoTi}_{1-x} \mathrm{Al}_{x}$ was studied by Jezierski and Borstel [33]. The self-consistent LMTO and CPA calculations indicated that in $\mathrm{CoTi}_{1-x} \mathrm{Al}_{x}$ a part of the cobalt atoms occupied the $\mathrm{Ti}$ or $\mathrm{Al}$ position [33,34].

The organization of this paper is the following. In Sec. 2 we present the outline of a method of calculation of the electronic structure. The calculated total and local density of states for $\mathrm{Pd}_{2} \mathrm{TiAl}$ are presented in Sec. 3. The electronic structure and the dependence of the density of states at the Fermi level in $\mathrm{Ni}_{2}\left(\mathrm{Nb}_{(1-x)} \mathrm{T}_{x}\right) \mathrm{Sn}$ for $\mathrm{T}=\mathrm{Ti}$ and $\mathrm{Ta}$ are shown in Sec. 4. Finally in Sec. 5 we present the electronic and magnetic properties of series $\mathrm{Rh}_{2} \mathrm{TMSn}(\mathrm{TM}=\mathrm{Mn}, \mathrm{Fe}, \mathrm{Co}, \mathrm{Ni}, \mathrm{Cu}$ ) and $\mathrm{Rh}_{2} \mathrm{MnX}(\mathrm{X}=\mathrm{Al}, \mathrm{Ga}, \mathrm{In}, \mathrm{Ge}, \mathrm{Sb}, \mathrm{Pb})$ Heusler-type alloys.

\section{Method of calculation}

The Heusler-type compounds crystallize in $L 2_{1}$-type structure (Fig. 1 ). The $L 2_{1}$-type structure consists of four interpenetrating fcc sublattices based at $(0,0,0)$, $(0.5,0.5,0.5),(0.25,0.25,0.25)$ and $(0.75,0.75,0.75)$. In $\mathrm{Pd}_{2} \mathrm{TiAl}$ system, the palladium atoms occupy two fcc sublattices at $(0.25,0.25,0.25)$ and $(0.75,0.75,0.75)$. The sublattices located at $(0,0,0)$ and $(0.5,0.5,0.5)$ are taken by titanium and aluminum atoms. In $L 2_{1}$-type structure the distance between $\mathrm{Pd}$ atoms is equal to half of the lattice parameter and each palladium atom has $\mathrm{Ti}$ or $\mathrm{Al}$ atoms as the nearest neighbors. In $\mathrm{Co}_{2-x} \mathrm{Ni}_{x} \mathrm{TiSn}, \mathrm{Co}_{2} \mathrm{Ti}_{1-x} \mathrm{Al}_{x}$ or $\mathrm{Ni}_{2}\left(\mathrm{Nb}_{(1-x)} \mathrm{Ti}_{x}\right) \mathrm{Sn}$ alloys we observe a disorder in one fcc sublattice. We can consider two effects: substituting one type of atom by another or change of the position of atoms in cell for the fixed concentration. Both effects will be discussed below. The electronic densities of states of the ordered Heusler $\left(L 2_{1}\right)$ alloys were calculated by using the spin-polarized self-consistent LMTO method [38]. The exchange correlation potential was assumed in the form proposed by von Barth and Hedin [39] and Langreth-Mehl-Hu (LMH) corrections [40] were included. The self-consistent band calculations were carried out for $256 k$-points (for $\mathrm{Pd}_{2} \mathrm{TiAl}, \mathrm{Rh}_{2}$ TMSn (TM $=\mathrm{Mn}, \mathrm{Fe}, \mathrm{Co}, \mathrm{Ni}, \mathrm{Cu}$ ),

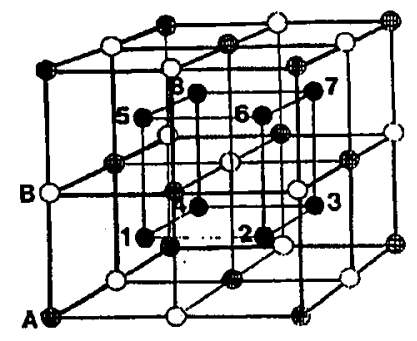

Fig. 1. The Heusler $L 2_{1}$ structure. 
and $\left.\mathrm{Rh}_{2} \mathrm{MnX}(\mathrm{X}=\mathrm{Al}, \mathrm{Ga}, \mathrm{In}, \mathrm{Ge}, \mathrm{Sb}, \mathrm{Pb})\right)$ in the irreducihle wedge of the Brillouin zone. In the case of supercell $\mathrm{Ni}_{16}\left(\mathrm{Nb}_{8(1-x)} \mathrm{T}_{8 x}\right) \mathrm{Sn}_{8}$ the number of $k$-points was 64 . In the band calculations we assumed the initial configurations according to the periodic table of elements. The electronic structures were computed for the experimental lattice parameter and the values of the Wigner-Seitz radii in the atomic sphere approximation (ASA) were chosen so as to fill the space completely.

\section{Electronic structure of $\mathbf{P d}_{2} \mathbf{T i A l}$}

One of the characteristic features of the Heusler alloys is existing magnetic ordering in the systems which consists of the non-magnetic elements. Neumann and co-workers [15-19] observed weak ferromagnetism in the new series of ternary intermetallic $\mathrm{Pd}_{2}$ TiSn and $\mathrm{Pd}_{2}$ TiAl compounds. The self-consistent LMTO band calculations $[27,32]$ did not confirm the magnetic ordering in $\mathrm{Pd}_{2} \mathrm{TiX}$ for $\mathrm{X}=\mathrm{Al}$, $\mathrm{Sn}$ and $\mathrm{In}$. The experimental local and total densities of states of $\mathrm{Pd}_{2} \mathrm{TiAl}$ were measured by Liddiard et al. $[17,18]$ using ultraviolet photoelectron spectroscopy (UPS) method. They observed the contribution to the density of states at the Fermi level from Ti $3 d$ and $\mathrm{Pd} 4 d$. The UPS results indicated that $\mathrm{Pd} 4 d$ band was not completely full. The band structures of the ordered $\mathrm{Pd}_{2} \mathrm{TiAl}$ alloy were computed by spin-polarized LMTO method [38]. The local and total densities of states for the ordered $\mathrm{Pd}_{2} \mathrm{TiAl}$ alloy calculated for the experimental lattice parameter are presented in Fig. 2. The Fermi level is located at $E=0 \mathrm{eV}$. The density of states (DOS) at the Fermi level is 46.5 (states/eV cell). The DOS consists of three parts: the lower part gives the contribution from $s$-states of $\mathrm{Al}$, the middle part contains mainly the contributions from the $d$-states of Pd and the part near the Fermi level shows the $d$-states of Ti. The gap between $s$-states of $\mathrm{Al}$ and $d$-states of $\mathrm{Pd}$ can be observed also in other Heusler alloys. The shape of total DOS for $\mathrm{Pd}_{2} \mathrm{TiAl}$ is close to experimental UPS result [18]. We observe the peaks in the similar positions as Liddiard et al. [18]. The plots of the local densities of states (Fig. 2) have shown the contribution from each atom to the total DOS. Our self-consistent spin-polarized band calculations based on the LMTO-ASA and the local spin density (LSD) approximation indicate that there was no magnetic moment either on $\mathrm{Ti}$ or on $\mathrm{Pd}$ atom as suggested by magnetic measurements $[15,16]$. In Fig. $3 a$ and $b$ we presented the charge densities for $\mathrm{Pd}_{2} \mathrm{TiAl}$. In Fig. $3 \mathrm{a}$ the charge densities for $\mathrm{Ti}$ and $\mathrm{Al}$ atoms in plane $(0,0,1)$ are plotted. The charge density for palladium atoms in plane $(0,0.5,1)$ is visualized in Fig. $3 \mathrm{~b}$. The calculations have shown that there are 10.08 electrons on the palladium atom $\left(n_{s}=0.66, n_{p}=0.70\right.$ and $n_{d}=8.72$ electrons). This result was confirmed by UPS experiment [18].

\section{The electronic structure of $\mathrm{Ni}_{16}\left(\mathrm{Nb}_{8(1-x)} \mathrm{T}_{8 x}\right) \mathrm{Sn}_{8}$ alloys}

The electronic structures of $\mathrm{Ni}_{2} \mathrm{XAl}(\mathrm{X}=\mathrm{Ti}, \mathrm{V}, \mathrm{Zr}, \mathrm{Nb}, \mathrm{Hf}$ and $\mathrm{Ta})$ Heusler intermetallic compounds were studied theoretically by Liu and Freeman [29]. Recently, Boff et al. [28] presented the specific heat measurements for $\mathrm{Ni}_{2}\left(\mathrm{Nb}_{(1-x)} \mathrm{Ti}_{x}\right) \mathrm{Sn}$ and $\mathrm{Ni}_{2}\left(\mathrm{Nb}_{(1-x)} \mathrm{Ta}_{x}\right) \mathrm{Sn}$ compounds. They observed the lattice anomalies in all systems. The electronic specific heat $\gamma$ coefficient changed with the concentration of $\mathrm{Ti}$ and $\mathrm{Ta}$ atoms. Unfortunately, the large experimental errors did not give the accurate information about the change of $\gamma$ coefficient with the concen- 


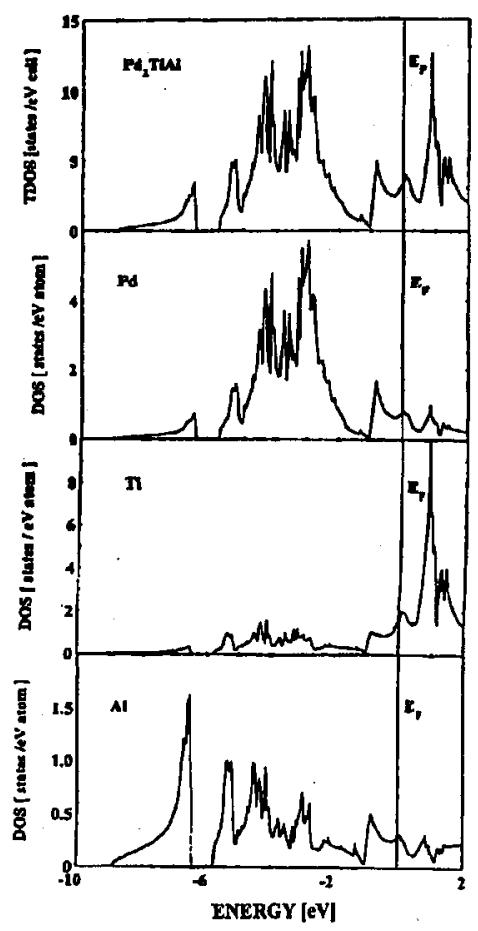

Fig. 2. The total and local DOS for $\mathrm{Pd}_{2}$ TiAl. The Fermi level $\left(E_{\mathrm{F}}\right)$ is marked by vertical line.
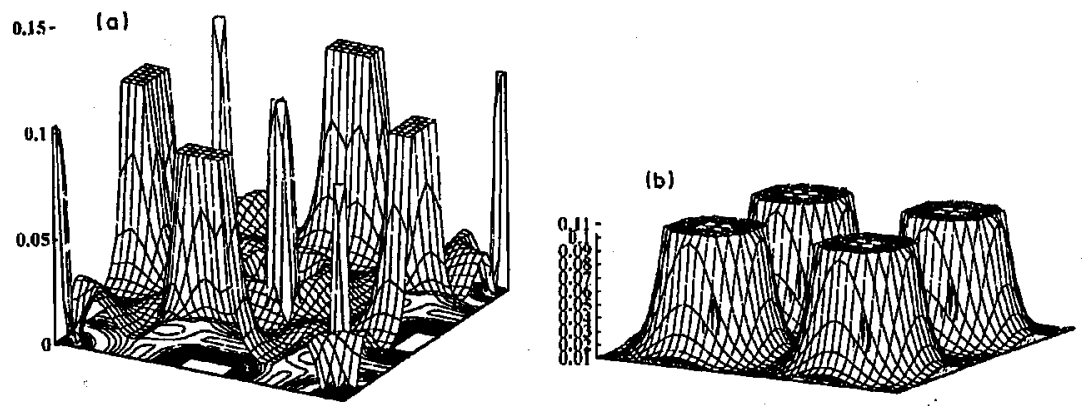

Fig. 3. The plot of the charge density for $\operatorname{Pd}_{2}$ TiAl: (a) origin $(0,0,0)$, (b) origin $(0.5,0,0)$.

tration. In this paper we present the electronic structure for $\mathrm{Ni}_{16}\left(\mathrm{Nb}_{8(1-x)} \mathrm{Ti}_{8 x}\right) \mathrm{Sn}_{8}$ and $\mathrm{Ni}_{2}\left(\mathrm{Nb}_{(1-x)} \mathrm{Ta}_{x}\right) \mathrm{Sn}$ alloys for $x=0.125$ and 250 . The band calculations were performed for the supercell of 32 atoms in order to change the concentration $x$ with step $x=0.125$ (one atom Ti or Ta) and $x=0.25$ (two atoms Ti or Ta) in the supercell. The supercell consists of two $L 2_{1}$ type structures with the basic vectors $(200),(010)$ and $(001)$. The supercell was occupied by $16 \mathrm{Ni}, 8 \mathrm{Sn},(8-8 x) \mathrm{Nb}$ and $8 x \mathrm{Ti}$ or $\mathrm{Ta}$ atoms. The $\mathrm{Ti}$ and $\mathrm{Ta}$ atoms were located at $(000)$ or $(100)$ 
positions. In the case of two $\mathrm{Ti}$ or $\mathrm{Ta}$ atoms we substituted the $\mathrm{Nb}$ atoms by $\mathrm{T}$ atoms in the different sites of $\mathrm{Nb}$ sublattice. We found that the structures with $\mathrm{T}$ atoms in the positions (000) and (100) had the lowest total energy. The values of density of states for the random distributed $\mathrm{T}$ atoms in $\mathrm{Nb}$ sublattice were greater than for ordered structures but in those cases the systems were unstable. It seems that the values of the $\gamma$ coefficient depend strongly on the preparation of samples. The self-consistent band calculations were performed for $\mathrm{Ni}_{16} \mathrm{Nb}_{8} \mathrm{Sn}_{8}$, $\mathrm{Ni}_{16}\left(\mathrm{Nb}_{8(1-x)} \mathrm{Ti}_{8 x}\right) \mathrm{Sn}_{8}$ and $\mathrm{Ni}_{16}\left(\mathrm{Nb}_{8(1-x)} \mathrm{Ta}_{8 x}\right) \mathrm{Sn}_{8}$ for $x=0.125$ and $x=0.250$. In Fig. 4 we plotted the total DOS for $\mathrm{Ni}_{16} \mathrm{Nb}_{8} \mathrm{Sn}_{8}, \mathrm{Ni}_{16} \mathrm{Nb}_{7} \mathrm{TiSn}_{8}, \mathrm{Ni}_{16} \mathrm{Nb}_{6} \mathrm{Ti}_{2} \mathrm{Sn}_{8}$, $\mathrm{Ni}_{16} \mathrm{Nb}_{7} \mathrm{TaSn}_{8}$ and $\mathrm{Ni}_{16} \mathrm{Nb}_{6} \mathrm{Ta}_{2} \mathrm{Sn}_{8}$ alloys. The Fermi level is located at the valley on the left side of the peaks. The substitution of one $\mathrm{Nb}$ by $\mathrm{Ti}$ or Ta atom leads to the decrease in the density of states at the Fermi level. The density of states at the Fermi level decreased from 33.95 (states/eV f.u.) for $\mathrm{Ni}_{16} \mathrm{Nb}_{8} \mathrm{Sn}_{8}$ to 29.53 (28.99) (states/eV f.u.) for $\mathrm{Ni}_{16} \mathrm{Nb}_{6} \mathrm{Ti}_{2} \mathrm{Sn}_{8}\left(\mathrm{Ni}_{16} \mathrm{Nb}_{6} \mathrm{Ta}_{2} \mathrm{Sn}_{8}\right)$, respectively.
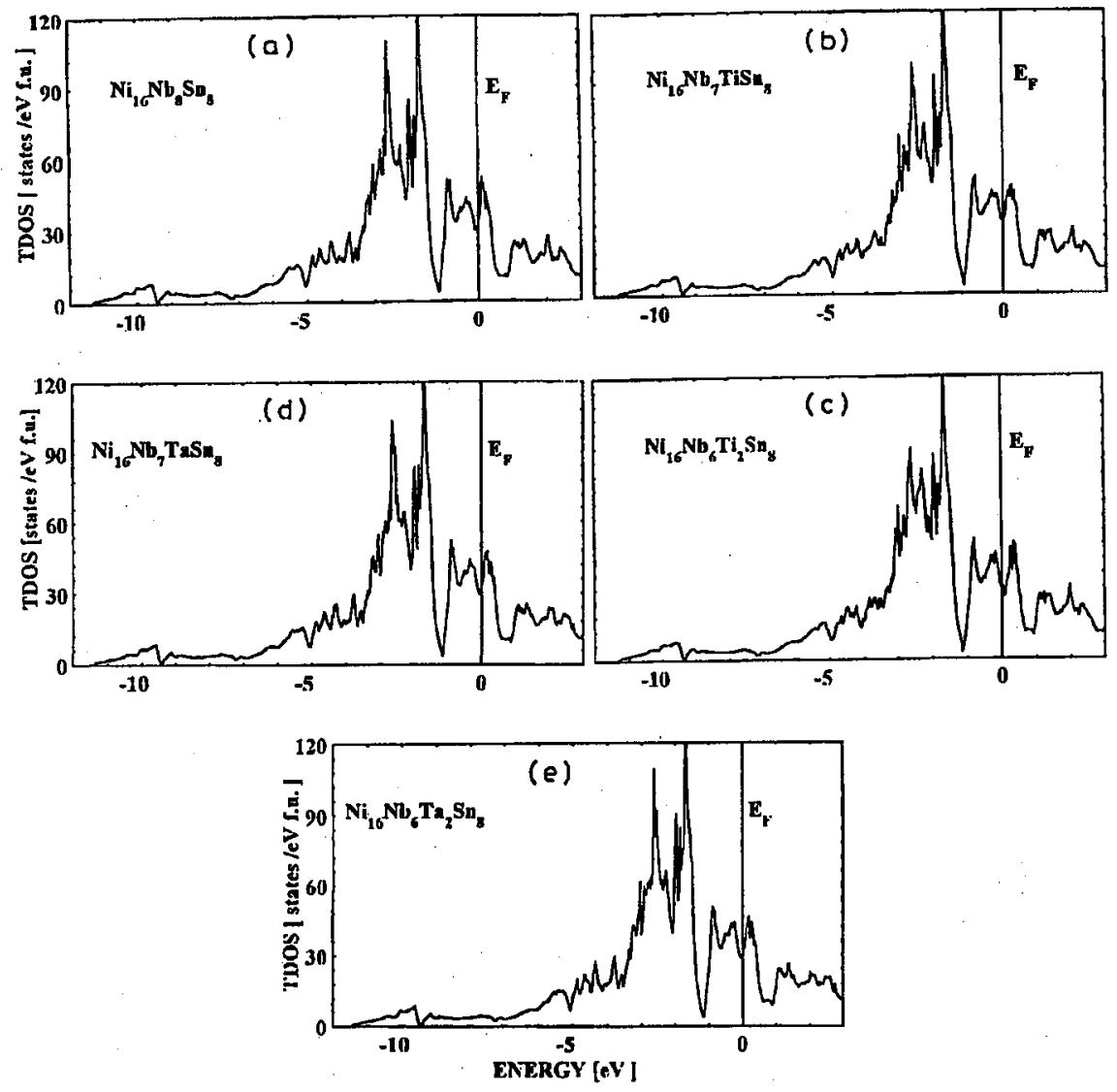

Fig. 4. The total DOS for (a) $\mathrm{Ni}_{16} \mathrm{Nb}_{8} \mathrm{Sn}_{8}$, (b), (c) $\mathrm{Ni}_{16} \mathrm{Nb}_{8(1-x)} \mathrm{Ti}_{8 x} \mathrm{Sn}_{8}$, (d), (e) $\mathrm{Ni}_{16} \mathrm{Nb}_{8(1-x)} \mathrm{Ta}_{8 x} \mathrm{Sn}_{8}$ for $x=0.125$ and $x=0.25$. 
The measurements of the specific heat [28] indicated that the $\gamma$ coefficient decreased with the increase in Ti concentration, however for Ta alloys Boff et al. [28] observed the opossite tendency. The experimental results depended strongly on annealing the samples.

\section{Magnetism in $\mathbf{R h}_{2} \mathbf{T M X}$ Heusler-type alloys \\ $(\mathrm{TM}=\mathrm{V}, \mathrm{Mn}, \mathrm{Fe}, \mathrm{Co}, \mathrm{Ni}, \mathrm{Cu} ; \mathrm{X}=\mathrm{Al}, \mathrm{Ga}, \mathrm{In}, \mathrm{Ge}, \mathrm{Sn}, \mathrm{Pb}, \mathrm{Sb})$}

Magnetic properties of the series $\mathrm{Rh}_{2} \mathrm{TMX}$ Heusler-type alloys (where TM denotes a transition metal $\mathrm{V}, \mathrm{Cr}, \mathrm{Mn}, \mathrm{Fe}, \mathrm{Co}, \mathrm{Ni}, \mathrm{Cu}$ and $\mathrm{X}$ is a non-magnetic element $\mathrm{Al}, \mathrm{Ga}, \mathrm{In}, \mathrm{Ge}, \mathrm{Sn}, \mathrm{Pb}, \mathrm{Sb}$ ) have been investigated experimentally and theoretically in the last decade [1-12]. The large group of Heusler compounds crystallized in the cubic $L 2_{1}$ type structure (Fig. 1). For $\mathrm{TM}=\mathrm{Cr}, \mathrm{Fe}, \mathrm{Co}$ and $\mathrm{X}=\mathrm{Sn}, \mathrm{Sb}$ a tetragonal distortion $(c / a=1.11-1.21)$ was observed. The values of the magnetic moments in $\mathrm{Rh}_{2} \mathrm{TMX}$ alloys depend strongly on the type of transition metal and the sample preparation. The measurements of magnetization, hyperfine fields, reciprocal susceptibility versus temperature give only information about the total magnetic moments. The experimental values of the magnetic moments for the similar systems depended on the method of measurements and sample preparation. In this paper we present the systematical study of the electronic

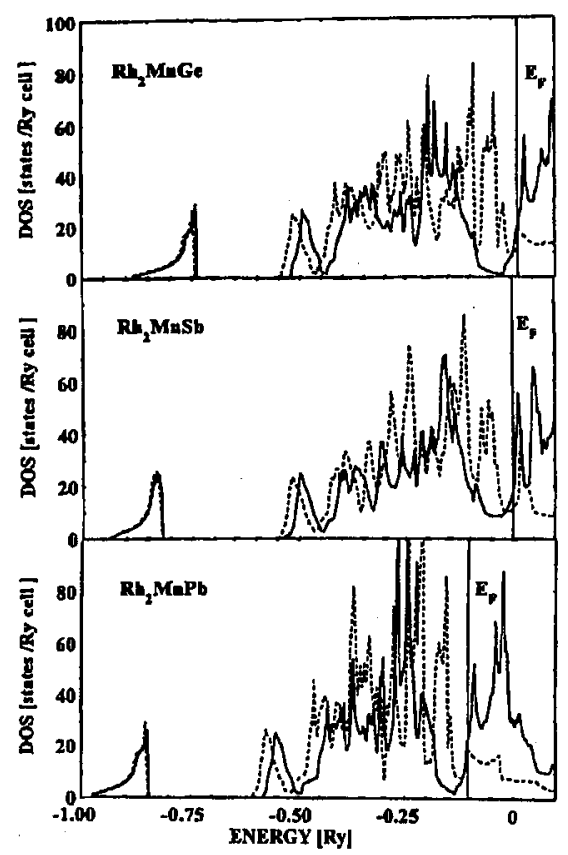

Fig. 5. The total density of states in $\mathrm{Rh}_{2} \mathrm{Mn}(\mathrm{Ge}, \mathrm{Sb}, \mathrm{Pb})$. 


\section{TABLE I}

The lattice parameters and the magnetic moments in $\mathrm{Rh}_{2} \mathrm{MnX}$ alloys.

\begin{tabular}{l|c|c|c|c|c|c}
\hline \multicolumn{1}{c|}{$x$} & $\mathrm{Al}$ & $\mathrm{Ga}$ & $\mathrm{In}$ & $\mathrm{Sb}$ & $\mathrm{Ge}$ & $\mathrm{Pb}$ \\
\hline$a$ [a.u. $]$ & 11.35 & 11.44 & 11.86 & 11.15 & 11.33 & 11.97 \\
$c / a$ & 1.0 & 1.0 & 1.0 & 1.17 & 1.0 & 1.0 \\
$m_{t}\left[\mu_{\mathrm{B}}\right]$ & 4.04 & 4.10 & 4.11 & 4.29 & 4.36 & 4.54 \\
$m_{\mathrm{Rh}}\left[\mu_{\mathrm{B}}\right]$ & 0.35 & 0.36 & 0.34 & 0.31 & 0.37 & 0.40 \\
$m_{\mathrm{Mn}}\left[\mu_{\mathrm{B}}\right]$ & 3.38 & 3.42 & 3.45 & 3.67 & 3.61 & 3.74 \\
$m_{x}\left[\mu_{\mathrm{B}}\right]$ & -0.04 & -0.04 & -0.01 & 0.01 & 0.01 & 0.01
\end{tabular}

TABLE II

The lattice parameters and the magnetic moments in $\mathrm{Rh}_{2} \mathrm{TMSn}$ alloys.

\begin{tabular}{l|c|c|c|c|c}
\hline \hline \multicolumn{1}{c|}{$\mathrm{TM}$} & $\mathrm{Mn}$ & $\mathrm{Fe}$ & $\mathrm{Co}$ & $\mathrm{Ni}$ & $\mathrm{Cu}$ \\
\hline$a$ [a.u. $]$ & 11.80 & 13.07 & 13.06 & 11.80 & 11.62 \\
$c / a=1.0$ & 1.0 & 1.18 & 1.19 & 1.0 & 1.0 \\
$m_{t}\left[\mu_{\mathrm{B}}\right]$ & 4.51 & 4.60 & 3.20 & 0.79 & 0.0 \\
$m_{\mathrm{Rh}}\left[\mu_{\mathrm{B}}\right]$ & 0.38 & 0.52 & 0.52 & 0.19 & 0.0 \\
$m_{\mathrm{TM}}\left[\mu_{\mathrm{B}}\right]$ & 3.77 & 3.59 & 2.21 & 0.42 & 0.0 \\
$m_{\mathrm{Sn}}\left[\mu_{\mathrm{B}}\right]$ & -0.02 & -0.05 & -0.06 & -0.01 & 0.0
\end{tabular}

structure and magnetic properties of the series of $\mathrm{Rh}_{2} \mathrm{TMSn}$ and $\mathrm{Rh}_{2} \mathrm{MnX}$ (for $\mathrm{TM}=\mathrm{Mn}, \mathrm{Fe}, \mathrm{Co}, \mathrm{Ni}, \mathrm{Cu}$ and $\mathrm{X}=\mathrm{Al}, \mathrm{Ga}, \mathrm{In}, \mathrm{Ge}, \mathrm{Sb}, \mathrm{Pb}$ ) ordered alloys by spin-polarized self-consistent TB-LMTO method [38]. Our attention is focused on the dependence of the local magnetic moment at rhodium atom on the type of transition element in $\mathrm{Rh}_{2} \mathrm{TMX}$ alloys. The band calculations were performed for the experimental lattice parameters. As example in Fig. 5 we presented the total densities of states for $\mathrm{Rh}_{2} \mathrm{Mn}(\mathrm{Ge}, \mathrm{Sb}, \mathrm{Pb})$ ordered alloys. The solid lines present the DOS for the majority spin bands, and the broken curves show the DOS for the minority spin bands. The Fermi level $E_{\mathrm{F}}$ is denoted by the vertical line. In all systems we observe a gap between $s$-band of X-element and $s-, p$-, $d$-bands of TM metals. Such a gap is a characteristic feature of the Heusler alloys and the values of the gap depend on the type of system. In $\mathrm{Rh}_{2} \mathrm{MnX}$ alloys there is a deep valley in the majority spin band and the Fermi level is located on the right side of the valley. The values of lattice parameters in the atomic units (a.u.), the total and local magnetic moments are listed in Table I and II. The spin-polarized TB-LMTO calculations have shown that the magnetic moment in $\mathrm{Rh}_{2} \mathrm{MnX}(\mathrm{X}=\mathrm{Al}, \mathrm{Ga}$, $\mathrm{In}, \mathrm{Ge}, \mathrm{Sb}$ and $\mathrm{Pb}$ ) was localized on manganese atom and changed from 3.38 to $3.79 \mu_{\mathrm{B}}$ (Table I). The magnetic moment on rhodium atom was small $\left(0.3-0.4 \mu_{\mathrm{B}}\right)$. 
The total magnetic moment in $\mathrm{Rh}_{2} \mathrm{TMSn}$ for $\mathrm{TM}=\mathrm{Mn}, \mathrm{Fe}, \mathrm{Co}, \mathrm{Ni}, \mathrm{Cu}$ decreased from $4.6 \mu_{\mathrm{B}}(\mathrm{Fe})$ to zero for Cu (Table II).

\section{Conclusions}

The electronic and magnetic properties of Heusler-type alloys depend strongly on the distribution of atoms in unit cell. We considered in this paper the effect of disorder at $\mathrm{Nb}-\mathrm{Ti}(\mathrm{Ta})$ sublattice in $\mathrm{Ni}_{16} \mathrm{Nb}_{8(1-x)} \mathrm{T}_{\dot{8}_{x}} \mathrm{Sn}_{8}$ alloys for $\mathrm{T}=\mathrm{Ti}$ and Ta. The difference between experimental and theoretical results can be connected with the samples preparation. Our self-consistent TB-LMTO results for $\mathrm{Pd}_{2} \mathrm{TiAl}$ alloy have shown the strong correlation between UPS measurements and ab initio calculations.

\section{Acknowledgment}

This research was supported by the Committee for Scientific Research through project No. 2 P302 00507.

\section{References}

[1] F.A. Hames, J. Crangle, J. Appl. Phys. 42, 1336 (1971).

[2] J.C. Suits, Solid State Commun. 18, 423 (1976).

[3] J.C. Suits, Phys. Rev. B 14, 4131 (1976).

[4] C.C.M. Campbell, T. Birchall, J.C. Suits, J. Phys. F 7, 727 (1977).

[5] J. Itoh, K. Shimizu, H. Mizutani, A.K. Grover, L.C. Gupta, R. Vijayaraghavan, J. Phys. Soc. Japan 42, 1777 (1977).

[6] R.G. Pillay, P.N. Tandon, Phys. Status Solidi A 45, K109 (1978).

[7] S.K. Dhar, A.K. Grover, S.K. Malik, R. Vijayaraghavan, Solid State Commun. 33, 545 (1980).

[8] R.G. Pillay, A.K. Grover, P.N. Tandon, Le Dang Khoi, P. Veillet, J. Magn. Magn. Mater. 15-18, 647 (1980).

[9] K.H.J. Bushow, P.G. van Engen, R. Jongebreur, J. Magn. Magn. Mater. 38, 1 (1983).

[10] R.A. Dunlap, S. Jha, G.M. Julian, Can. J. Phys. 62, 396 (1984).

[11] S. Jha, H.M. Seyoum, G.M. Julian, R.A. Dunlap, A. Vasquez, J.G.M. da Cunha, S.M.M. Ramos, Phys. Rev. B 32, 3279 (1985).

[12] P.J. Webster, K.R.A. Ziebeck, in: Landolt-Bornstein New Series 1990, Group III, Vol. 19, Magnetic Properties of Metals, Subvolume C, Springer, Berlin 1990, p. 75.

[13] J. Pierre, R.V. Skolozdra, Yu.V. Stadnyk, J. Magn. Magn. Mater. 128, 93 (1993).

[14] J. Pierre, R.V. Skolozdra, Yu.K. Gorelenko, M. Konacou, J. Magn. Magn. Mater. 134, 95 (1994).

[15] K.-U. Neumann, J. Crangle, R.K. Kremer, N.K. Zayer, K.R.A. Ziebeck, J. Magn. Magn. Mater. 127, 47 (1993).

[16] O. Ouladdiaf, K.-U. Neumann, J. Crangle, N.K. Zayer, K.R.A. Ziebeck, E. Ressouche, J. Phys. Condens. Matter 6, 1563 (1994).

[17] A.J. Liddiard, M.D. Crapper, N.D. Telling, P.A. Skull, M. Petty, N.K. Zayer, J.G. Smith, K.-U. Neumann, K.R.A. Ziebeck, J. Magn. Magn. Mater. 140-144, 187 (1995). 
[18] A.J. Liddiard, D. Brown, M.D. Crapper, M. Petty, J.G. Smith, N.D. Telling, K.H. Bedwell, L.B. Flannery, P.A. Skull, J. Phys. Condens. Matter 8, 3955 (1996).

[19] K.-U. Neumann, J. Crangle, S. Lipinski, J.G. Smith, N.K. Zayer, K.R.A. Ziebeck, J. Magn. Magn. Mater. 140-144, 195 (1995).

[20] S. Ishida, S. Akazawa, Y. Kubo, J. Ishida, J. Phys. F, Met. Phys. 12, 1111 (1982).

[21] S. Ishida, J. Ishida, S. Asano, J. Yamashita, J. Phys. Soc. Japan 45, 1239 (1978).

[22] S. Ishida, S. Sugimura, S. Fujii, S. Asano, J. Phys. Condens. Matter 3, 5793 (1991).

[23] S. Ishida, Y. Kubo, J. Ishida, S. Asano, J. Phys. Soc. Japan 48, 814 (1980).

[24] S. Fuji, S. Sugimura, S. Ishida, S. Asano, J. Phys. Condens. Matter 2, 8583 (1990).

[25] J. Kubler, A.R. Williams, C.B. Sommers, Phys. Rev. B 28, 1745 (1983).

[26] P. Mohn, P. Blaha, K.J. Schwarz, J. Magn. Magn. Mater. 140-144, 183 (1995).

[27] S.S. Jaswal, J. Magn. Magn. Mater. 139, L1 (1995).

[28] M.A.S. Boff, G.L.F. Fraga, D.E. Brandao, A.A. Gomes, J. Magn. Magn. Mater. 153, 135 (1996).

[29] W. Liu, A.J. Freeman, Phys. Rev. B 45, 61 (1992).

[30] M. Pugacheva, A. Szajek, A. Jezierski, Acta Phys. Slov. 46, 133 (1996).

[31] M. Pugacheva, A. Jezierski, J. Magn. Magn. Mater. 151, 202 (1995).

[32] A. Jezierski, J.A. Morkowski, A. Szajek, M. Pugacheva, J. Phys. Condens. Matter 7, 4447 (1995).

[33] A. Jezierski, G. Borstel, Physica B 205, 397 (1995).

[34] A. Jezierski, J. Magn. Magn. Mater. 140-144, 91 (1995).

[35] A. Jezierski, Phys. Status Solidi B 190, 471 (1995).

[36] A. Jezierski, Phys. Status Solidi B 196, 357 (1996).

[37] J. Tobola, J. Pierre, S. Kaprzyk, R.V. Skolozdra, M.A. Kouacou, J. Magn. Magn. Mater. 159, 192 (1996).

[38] O.K. Andersen, O. Jepsen, M. Sob, in: Electronic Band Structure and Its Applications, Springer Verlag Lecture Notes in Physics, Vol. 283, Ed. M. Yussouff, Springer, Berlin 1987, p. 1.

[39] U. von Barth, L. Hedin, J. Phys. C 5, 1629 (1972).

[40] C.D. Hu, D.C. Langreth, Phys. Scr. 32, 391 (1985). 